\title{
Gender standards and expectations on sexual deviations in the gender culture of Ukraine
}

\section{Ivan Svyatnenko, Classical Private University}

This article is devoted to the definition of the value structures of gender culture in aspects of gender stereotypes regarding the application of moral-pedagogical and legal sanctions in the manifestations of deviant behavior on the basis of the ideology of matriarchal racism (mysandry) and typical problems arising from its availability.

The writings of the authors form the theoretical basis for the author's theory, which consists essentially of the following key provisions set forth in the article:

1) latent gender racism in Ukrainian gender culture is an ideology of double standards, which involves parallel promotion and prohibition in the area of sexual norms and deviations for men and women;

2) Gender stereotypes refer to the assessment of male sexual behavior as subject to enhanced moral, legal and pedagogical control over women's sexual behavior;

3 ) the cultivation of homophobia is an instrument of gender power that allows women to manipulate men by imposing a number of prohibitions on public male homoeopathy in encouraging women's similar behavior;

4) stigmatization of homeroticism allows it to be used as a tool of social control, including the system of political security, in which the family acts as a grass root.

As a result of the study, the author concludes that the study of the ideology and morality of latent gender racism in the gender culture of Ukraine has allowed to dismiss most of the assumptions about egalitarian peculiarities of gender positioning for male and female respondents. At the same time, the regime of privilege, available to the Ukrainian gender culture, makes it possible to define gender scenarios as matriarchal-racist and those that are agreed upon by both men and women.

The consensual nature of such a situation proves not only the tacit consent of most with the guidelines of gender racism, but also the lack of understanding of the policy of gender equality of the western type. Such misunderstanding minimizes the chances of establishing an egalitarian gender culture and contributes to further deepening both gender inequality and the resulting gender conflict of Ukrainian society with all its implications.

Keywords: gender standartts; gender expectations; sexual deviation; gender ideology; gender moral gender racism; gender stereotypes; homophobia; gender power; gender rules; gender deviation

\section{Гендерні стандарти та очікування щодо сексуальних відхилень у гендерній культурі України}

\section{Іван Святненко, Класичний приватний університет}

Стаття присвячена визначенню ціннісних структур гендерної культури в аспектах гендерних стереотипів щодо застосування морально-педагогічних та правових санкцій у проявах девіантної поведінки на основі ідеології матріархального расизму (типології) та типових проблем, що виникають з ії наявності.

Твори авторів формують теоретичну основу теорії автора, яка складається з основних положень, викладених у статті:

1) латентний гендерний расизм в українській гендерній культурі є ідеологією подвійних стандартів, що передбачає паралельне просування і заборону в сфері сексуальних норм і відхилень для чоловіків і жінок;

2) Гендерні стереотипи належать до оцінки сексуальної поведінки чоловіків як суб’єктів підвищеного морального, правового та педагогічного контролю за сексуальною поведінкою жінок;

3) вирощування гомофобії є інструментом гендерної влади, що дозволяє жінкам маніпулювати чоловіками, накладаючи ряд заборон на публічну чоловічу гомеопатію, заохочуючи подібну поведінку жінок;

4) стигматизація гомоеротизму дозволяє використовувати іiї як інструмент соціального контролю, включаючи систему політичної безпеки, в якій сім’я виступає як коріння.

В результаті дослідження автор приходить до висновку, що вивчення ідеології та моральності латентного гендерного расизму в гендерній культурі України дозволило відкинути більшість припущень про егалітарні особливості гендерного позиціонування для чоловіків і жінок. Водночас режим привілеїв, до- 
ступний українській гендерній культурі, дає змогу визначити гендерні сценарії як матріархально-расистські і ті, які узгоджуються як з чоловіками, так і з жінками.

Консенсусний характер такої ситуації доводить не тільки мовчазну згоду більшості з принципами гендерного расизму, а й нерозуміння політики гендерної рівності західного типу. Таке непорозуміння мінімізує шанси на створення егалітарної гендерної культури і сприяє подальшому поглибленню як гендерної нерівності, так і гендерного конфлікту в українському суспільстві з усіма його наслідками.

Ключові слова: гендерні стандарти; гендерні очікування; сексуальне відхилення; гендерна ідеологія; гендерний моральний гендерний расизм; гендерні стереотипи; гомофобія; гендерна влада; гендерні правила; гендерні відхилення

\section{Гендерные стандарты и ожидания от половых отклонений в гендерной культуре Украины}

\section{Иван Святненко, Классического приватного университета}

Статья посвящена определению ценностных структур гендерной культуры в аспектах гендерных стереотипов по применению морально-педагогических и правовых санкций в проявлениях девиантного поведения на основе идеологии матриархального расизма (типологии) и типичных проблем, возникающих с ее наличия.

Произведения авторов формируют теоретическую основу теории автора, состоит из основных положений, изложенных в статье:

1) латентный гендерный расизм в украинской гендерной культуре является идеологией двойных стандартов, предусматривает параллельное продвижение и запрет в сфере сексуальных норм и отклонений для мужчин и женщин;

2) Гендерные стереотипы относятся к оценке сексуального поведения мужчин как субъектов повышенного морального, правового и педагогического контроля за сексуальным поведением женщин;

3) выращивание гомофобии является инструментом гендерной власти, позволяет женщинам манипулировать мужчинами, накладывая ряд запретов на публичную мужскую гомеопатию, поощряя подобное поведение женщин;

4) стигматизация гомоэротизма позволяет использовать ее как инструмент социального контроля, включая систему политической безопасности, в которой семья выступает как корни.

В результате исследования автор приходит к выводу, что изучение идеологии и нравственности латентного гендерного расизма в гендерной культуре Украины позволило отбросить большинство предположений об эгалитарной особенности гендерного позиционирования для мужчин и женщин. В то же время режим привилегий, доступный украинской гендерной культуре, позволяет определить гендерные сценарии как матриархально-расистские и те, которые согласуются как с мужчинами, так и с женщинами.

Консенсусный характер такой ситуации доказывает не только молчаливое согласие большинства с принципами гендерного расизма, но и непонимание политики гендерного равенства западного типа. Такое недоразумение минимизирует шансы на создание эгалитарной гендерной культуры и способствует дальнейшему углублению как гендерного неравенства, так и гендерного конфликта в украинском обществе со всеми его последствиями.

Ключевые слова: гендерные стандарты; гендерные ожидания; сексуальное отклонение; гендерная идеология; гендерный моральный гендерный расизм; гендерные стереотипы; гомофобия; гендерная власть; гендерные правила; гендерные отличия

Relevance of research.

7 his article is devoted to the definition of the value structures of gender culture in aspects of gender stereotypes regarding the application of moral-pedagogical and legal sanctions in the manifestations of deviant behavior on the basis of the ideology of matriarchal racism (mysandry) and typical problems arising from its availability.
In addition, the subject of the study is the definition of models of hidden gender power and gender stereotypes about the attitude of women to meeting the basic needs of men for recreation, health and social protection. The urgency of the analysis of these dimensions of gender culture is due to their weak research in Ukrainian sociology at significant influence of gender culture on social consciousness and behavior. 
The purpose and objectives of the article.

The purpose of the article is to identify gender scenarios, gender sanctions and gender discusions regarding deviant behavior.

An uncertain scientific problem, which is devoted to the article.

The article is devoted to the research of the ideology and morality of latent gender racism in the gender culture of Ukraine.

An analysis of recent research and publications in which the scientific problem has been initiated.

The theoretical and methodological principles of the research are presented in the works of Yu. Romanenko, Sh. Bern, T. Bendas, M. Burgin, G. Vizhelpova, M. Dobbin, and several author publications devoted to the problems of valuable principles of gender culture [1-13].

The writings of the authors form the theoretical basis for the author's theory, which consists essentially of the following key provisions set forth in the article:

1) latent gender racism in Ukrainian gender culture is an ideology of double standards, which involves parallel promotion and prohibition in the area of sexual norms and deviations for men and women;

2) Gender stereotypes refer to the assessment of male sexual behavior as subject to enhanced moral, legal and pedagogical control over women's sexual behavior;

3 ) the cultivation of homophobia is an instrument of gender power that allows women to manipulate men by imposing a number of prohibitions on public male homoeopathy in encouraging women's similar behavior;

4) stigmatization of homeroticism allows it to be used as a tool of social control, including the system of political security, in which the family acts as a grass root.

\section{Presenting main material.}

The answer of the respondents on the fourth question allowed verifying / falsifying hypotheses, according to which:

1) in assessing the deviant erotic and sexual behavior of men and women, there are twofold gender standards: intonational / repressive standards for the assessment of erotic and sexual behavior of men and tolerant / inhuman (standard) standards for the assessment of similar deviant behavior among women.

2) in the circumstances of committing one and the same moral misconduct, the reaction to the behavior of women is more often of a lesser or lesser degree, whereas in relation to men, similar misconduct causes expressive and repressive sanctions in the form of emotional and physical violence;

3 ) the female part of the respondents reveals gender solidarity in ignoring or perpetrating erotic and sexual misconduct about their gender group and gender racism in assessing the sexual and gender-based misconduct of the male gender group;

4) The probable higher level of homophobia, which is derived from demonizing and scotomizing stereotypes about male sexuality in the Ukrainian gender culture, is probably the factor behind the possible application of more stringent moral, pedagogical and physical sanctions on erotic and sexual misconduct of young men by male respondents. To confirm the hypothesis, we analyze the data presented in Table 1.

According to empirical data, the respondents from both sexes (men and women) have almost the same number of neglected reactions (70 and 73\% respectively) regarding the homoeurotic behavior of young women in a public place. There are no significant differences between men and women in the application of conditional moral sanctions: $31.4 \%$ for young men by respondents of both sexes and $29.7 \%$ for young women by respondents from both sexes. The use of expressive forms of moral and ethical repression shows quantitative advantages among respondents of both sexes regarding young men.

If for the young women the tactics of loud indignation and reading of the notation about the inadmissibility of homoeurotic behavior would be realized by $10.2 \%$ of respondents of both sexes, then $33.2 \%$ of respondents would have done this for men. Respondents in double standards also demonstrate the use of additional (along with notation and emotional outrage) measures of public pressure on young men compared with young women. With regard to the homosexual behavior of young women in the public place, only $7.6 \%$ of the respondents of both sexes expressed readiness to draw the attention of other participants in the public situation (for example, in the questionnaire - other passengers in public transport).

As for young men, the number of potentially ready-to-read notations with elements of emotional disturbance and the inclusion of public pressure grows tenfold (up to $71.4 \%$ ). Significant 
Evaluating Gender Standards for Deviant Behavior Evaluation for Two Gender Groups

4. Imagine that you have witnessed the following situation. You go by public transport (bus, trolleybus, metro) and see two young men (young women) who cling to each other unhurriedly with each other. Determine how you react to this situation with men and women? (Choose only one answer option)

\begin{tabular}{|c|c|c|c|}
\hline \multicolumn{2}{|c|}{ 4.1. YOUTH MEN } & \multicolumn{2}{|c|}{ 4.2. YOUTH WOMEN } \\
\hline 4.1.1. Would n & Id not pay) any & 4.2.1. Would & Id not pay) any \\
\hline $\begin{array}{l}M A N \\
\% 11,6\end{array}$ & $\begin{array}{c}\text { WOMAN, } \\
\% 23,2\end{array}$ & $\begin{array}{l}M A N, \\
\% 73,8\end{array}$ & $\begin{array}{c}\text { WOMAN, } \\
\% 70,0\end{array}$ \\
\hline
\end{tabular}

4.1.2. He would have made (make) his 4.2.2. He would have made (make) his remarks, confining himself to this remarks, confining himself to this

\begin{tabular}{|c|c|c|c|}
\hline MAN, & WOMAN, & MAN, & WOMAN, \\
\% 15,6 & $\% 18,3$ & $\% 18,3$ & $\% 11,4$ \\
\hline
\end{tabular}

4.1.3. Beginning (would start) loudly resent 4 4.2.3. Beginning (would start) loudly resent and read a notation about the and read a notation about the inadmissibility of such behavior. inadmissibility of such behavior.

\begin{tabular}{|c|c|c|c|}
\hline $\begin{array}{c}M A N, \\
y \% 19,2\end{array}$ & $\begin{array}{c}\text { WOMAN, } \\
y \% 14,0\end{array}$ & $\begin{array}{c}M A N, \\
y \% 2,0\end{array}$ & $\begin{array}{c}\text { WOMAN, } \\
\boldsymbol{y} \% 8,2\end{array}$ \\
\hline \multicolumn{2}{|c|}{$\begin{array}{l}\text { 4.1.4. It would have begun (begun) loudly to } \\
\text { resent and read the notation concerning the } \\
\text { inadmissibility of such behavior, as well as } \\
\text { to pay attention to other passengers what is } \\
\text { happening. }\end{array}$} & \multicolumn{2}{|c|}{$\begin{array}{l}\text { 4.2.4. It would have begun (begun) loudly to } \\
\text { resent and read the notation concerning the } \\
\text { inadmissibility of such behavior, as well as } \\
\text { to pay attention to other passengers what is } \\
\text { happening. }\end{array}$} \\
\hline $\begin{array}{c}\text { MAN, } \\
\boldsymbol{y} \% 35,8\end{array}$ & $\begin{array}{c}\text { WOMAN, } \\
\boldsymbol{y} \% 35,6\end{array}$ & $\begin{array}{c}M A N, \\
y \% 2,0\end{array}$ & $\begin{array}{c}\text { WOMAN, } \\
\boldsymbol{y} \% 5,6\end{array}$ \\
\hline \multicolumn{2}{|c|}{$\begin{array}{l}\text { 4.1.5. Applying (would apply) to them } \\
\text { physical aggression, having tried to remove } \\
\text { them from transport (bus, trolleybus, metro) }\end{array}$} & \multicolumn{2}{|c|}{$\begin{array}{l}\text { 4.2.5. Applying (would apply) to them } \\
\text { physical aggression, having tried to remove } \\
\text { them from transport (bus, trolleybus, metro) }\end{array}$} \\
\hline 20 & - & - & 7,0 \\
\hline
\end{tabular}


differences and the possibility of using extreme enforced sanctions against the deviant of two gender groups.

The number of women who would resort to a forceful repression of young women's homosexual behavior is three times less than the number of men who would have been subjected to physical aggression for the young men's homoeurotic behavior ( $7 \%$ and $20 \%$ respectively). At the same time, male respondents generally did not show desire $(0 \%)$ to reject the homoeurotic behavior of young women physically.

Answers to question 5 allow you to oversee the moral and ethical grounds that respondents choose to justify certain types of verbal and physical aggression regarding the homosexual behavior of young men and women. Here attention is paid to several empirical laws (see table 2.).

1) A little less than a third of respondents $(30 \%$ of respondents) believes that homoeurotic behavior of representatives of both sexes is quite normal and acceptable. The reasons for such intolerance may be the stereotypes of Soviet sexual morals, which implies only the hidden realization of sexuality and legitimizes the meticulous attitude to the manifestations of erotic behavior in public places by young people.

Since $70 \%$ of respondents of all age groups find this behavior unacceptable, we have grounds for the assumption that the evaluative representations of Soviet quasipuritanism (the ideology and morale of the ephemeral «liberation» of the Soviet man from sexual fantasies, desires, trains, etc.) are actual-reproducible and in experience young and older generation. In this case, it is not just about phobias of the representatives of the older age group (over 35 years old) about heterogeneous erotic behavior, but about the typical manifestations of homophobia for the Soviet man.

Y. Romanenko believes that the Soviet person's homophobia can be understood in the context of the graft model of repressive sublimation and the sexualization of violent behavior by representatives of the ruling class (party nomenklatura). The author proves - with which one can fully agree - that the experience of organized violence of party functionaries, their servvitaria, the Soviet totalitarian state with respect to ordinary «subjects» led to confusion in the representations of the ruling class of their own homosexual fantasies with destructive fantasies $[5$, p. 112-134; 7].
This is the mixing that may occur in connection with the pathological sexualization by the Bolsheviks of the practice of mass murder, the organized seizures of individual property and real estate of the population, which had its inevitable consequence of the demonization of any aggressive and sexual manifestations of men against each other.Since even an aggressor with dull censorship (conscience) is able to experience a sense of shame for his own crimes against the victim, the criminal ruling class, naturally, could not survive such a feeling.

The shame of unlawful aggression in the psyche can be generalized to the sexual sphere (since sexuality has its basis of aggression as such). At the same time, the projection of this shame on ordinary citizens has generated, on the one hand, the emergence of sexual shyness towards women, and on the other hand - homophobia in relation to men.

2) $42 \%$ of male respondents and $45 \%$ of women respondents believe that homoeurotic behavior is quite acceptable to women, but not acceptable to men.

That is, the legitimacy of the sexual morals of homosexual homosexuality (proto-lesbian behavior) of women and the «illegality» of a similar behavior for men. Thus, we can verify the hypothesis that in the Ukrainian sexual culture there are double standards for assessing the deviant behavior of men and women.And if deviant behavior of this kind (homeroticism) is allowed to women, then they are allowed and (add: encouraged) by men a variety of «liberties» in the field of sexual behavior. Moreover, women consider such liberties as «natural», and men join their minds as well.

Consequently, men themselves become supportive of double standards of sexual morals, which is typical of matriarchal racism and sexism. The ideology and morality of matriarchal racism and sexism justifies and implies the unlimited possibilities of women to regulate the physical behavior of men, the structuring of their physical and physical environment and the imposition of appropriate regimes for their satisfaction with physiological needs.

3) $20 \%$ of men and $22 \%$ of women consider it necessary to criminalize the facts of the assumption of homosexual behavior of men against each other. Only $2 \%$ of male respondents and $1 \%$ of women assume criminalization of such behavior for women. 
Here, important for conceptual understanding of such empirical phenomena are, on the one hand, the scotomization of men as a gender group in the Ukrainian sexual culture, and, on the other hand, the connection between matriarchal ideas about the husband and wife of a man and a neo-feudal Ukrainian state as a tent and serf.

Y. Romanenko rightly believes that the right to initiate manifestations of erotica and sexuality is the right to exercise power or to prohibit such a sale. According to the researcher, the Matriarchate is the political institution of Ukrainian neo-feudalism, which, through repressive sexual morals, controls the possible horizontal communications of men and uses stigmatization practices to protect oneself from dangerous group formation in the male community $[6, \mathrm{p} .60-113 ; 7]$.
Since Ukrainian neo-feudalism itself is kept on the alligator of the oligarchy and the servitarium, it is implanted through the sexual morality of homophobia, on the one hand, as a derivative of the political impotence and destructiveness of the ruling class, and on the other hand, the subculture matriarchal homosexuality of criminal service.

\section{Conclusions.}

The study of the ideology and morality of latent gender racism in the gender culture of Ukraine has allowed to dismiss most of the assumptions about egalitarian peculiarities of gender positioning for male and female respondents. At the same time, the regime of privilege, available to the Ukrainian gender culture, makes it possible to define gender scenarios as matriarchal-racist and those that are agreed upon by both men and women. The consensual nature of such a situation proves not

\section{Evaluating Gender Standards for Deviant Behavior Evaluation for Two Gender Groups}

\begin{tabular}{|c|c|c|}
\hline \multirow[t]{2}{*}{ ANSWERS POSSIBLE } & \multicolumn{2}{|c|}{$\begin{array}{l}\text { What would you be able to justify your } \\
\text { hypothesized reaction in the situation } \\
\text { described in question 4? (Choose only one } \\
\text { answer option). }\end{array}$} \\
\hline & $M A N, \%$ & WOMAN, \% \\
\hline $\begin{array}{l}\text { 5.1. This is quite normal and suppose, so it is } \\
\text { not worth paying attention to it }\end{array}$ & 12 & 18 \\
\hline $\begin{array}{l}\text { 5.2. This is worthy of condemnation, since } \\
\text { only the representatives of the opposite sex } \\
\text { can kiss. }\end{array}$ & 10 & 10 \\
\hline $\begin{array}{l}\text { 5.3. This is quite acceptable for women, but } \\
\text { not acceptable for men. }\end{array}$ & 42 & 45 \\
\hline $\begin{array}{l}\text { 5.4. This is morally acceptable to men, but } \\
\text { morally unacceptable for women. }\end{array}$ & 5 & 2 \\
\hline $\begin{array}{l}\text { 5.5. This is not morally acceptable to either } \\
\text { women or men. }\end{array}$ & 9 & 2 \\
\hline $\begin{array}{l}\text { 5.6. The consequence of such behavior for } \\
\text { men should be criminal punishment. }\end{array}$ & 20 & 22 \\
\hline $\begin{array}{l}\text { 5.7. The consequence of such behavior for } \\
\text { women should be criminal punishment. }\end{array}$ & 2 & 1 \\
\hline
\end{tabular}


only the tacit consent of most with the guidelines of gender racism, but also the lack of understanding of the policy of gender equality of the western type. Such misunderstanding minimizes the chances of establishing an egalitarian gender culture and contributes to further deepening both gender inequality and the resulting gender conflict of Ukrainian society with all its implications.

\section{БІБІЛІОГРАФІЧНІ ПОСИЛАННЯ}

1. Бендас Т. В. Гендерная психология / Т. В. Бендас. - СПб.: Питер, 2006. - 431 с.

2. Берн Ш. Гендерная психология / Ш. Берн. - СПб.: ПРАЙМ-ЕВРОЗНАК, 2002. - 320 с.

3. Бургин М. С. Аксиологические аспекты научных теорий / М. С. Бургин, В. И. Кузнецов. - Киев: Наукова думка, 1991. - 183 с.

4. Выжлецов Г. П. Аксиология: становление и основные этапы развития / Г. П. Выжлецов // Социально-политический журнал. - 1996. - № 1. - С. 86-99.

5. Романенко Ю. В. Візуалізації в медійно-комунікаційному просторі: соціо-системологічний підхід / Ю. В. Романенко, І. О. Святненко, А. А. Зінченко. - Київ: Вид-во ІМВ, 2014. - 436 с.

6. Романенко Ю. В. Етнічні ідентичності в дзеркалі тілесності та практик харчування / Ю. В. Романенко, І. О. Святненко, А. О. Поцелуйко, А. Ю. Тащенко, Ю. Ю. Мєдвєдєва. - Київ: Вид-во ДУТ, 2015. - 437 с.

7. Романенко Ю. В. Об архетипической мегаломании украинских женщин / Ю. В. Романенко. - Режим доступу: https://www.facebook.com/groups/181957542406967/

8. Святненко І. О. Насильство в гендерній культурі: проблема побудови типології (частина 1) / І. О. Святненко // Науково-теоретичний альманах «Грані». - 2017. - № 3. - С. 22-26

9. Святненко І. О. Насильство в гендерній культурі: проблема побудови типології (частина 2) / I. О. Святненко // Науково-теоретичний альманах «Грані». - 2017. - № 4. - С. 35-40.

10. Святненко І. О. Девіації в українській гендерній культурі: соціосистемологічний аспект / I. О. Святненко // Науково-теоретичний альманах «Грані». - 2017. - № 6. - С. 17-22.

11. Романенко Ю. В. Этническая идентичность: социосистемологическое измерение геополітики / за заг. ред. Ю. В. Романенка; авт. кол. Я. В. Зоська, Ю. Ю. Медведева, Ю. В. Романенко, И. А. Святненко, Н. В. Туленков, Е. А. Хомерики. - Киев: Меркьюри-Подолье, 2016. - 369 с.

12. Dobbins M.-P. Black Matriarchy: Transforming a Myth of Racism into a Class Model / M.-P Dobbins, J. Mulligan // Journal of Comparative Family Studies. - 1980. - Vol. 11. - № 2. - P. 195-217.

13. Шохин В. К. Философия ценностей и ранняя аксиологическая мысль / В. К. Шохин. - М.: Изд-во РУДН, 2006. $-457 \mathrm{c}$.

\section{REFERENCES}

1. Bendas, T.V. (2006). Gendernaja psihologija [Gender Psychology]. Saint Petersburg: Piter [in Russian].

2. Bern, Sh. (2002). Gendernaja psihologija [Gender psychology]. Saint Petersburg: PRAJM-EVROZNAK [in Russian]. 3. Burgin, M.S., \& Kuznecov, V.I. (1991). Aksiologicheskie aspekty nauchnyh teorij [Axiological aspects of scientific theories]. Kiev: Naukova dumka [inUkrainian].

4. Vyzhlecov, G.P. (1996). Aksiologija: stanovlenie i osnovnye jetapy razvitija [Aksiology: formation and main stages of development]. Social'no-politicheskij zhurnal, 1, 86-99 [in Russian].

5. Romanenko, Yu.V., Sviatnenko, I.O., \& Zinchenko, A.A. (2014). Vizualizatsii v mediino-komunikatsiinomu prostori: sotsio-systemolohichnyi pidkhid [Visualizations in the media-communication space: the socio-systemological approach]. Kyiv: Vyd-vo IMV [in Ukrainian].

6. Romanenko, Yu.V., Sviatnenko, I.O., Potseluiko, A.O., Tashchenko, A.Yu., \& Miedviedieva, Yu.Yu. (2015). Etnichni identychnosti $v$ dzerkali tilesnosti ta praktyk kharchuvannia [Ethnic Identities in the Mirror of Physicality and Food Practices]. Kyiv: Vyd-vo DUT [in Ukrainian].

7. Romanenko, Ju.V. Ob arhetipicheskoj megalomanii ukrainskih zhenshhin [On the archetypal megalomania of Ukrainian women]. Retrieved from: https://www.facebook.com/groups/181957542406967/ [in Russian].

8. Sviatnenko, I.O. (2017). Nasylstvo v hendernii kulturi: problema pobudovy typolohii (chastyna 1) [Violence in the gender culture: the problem of constructing a typology (part 1)]. Naukovo-teoretychnyi almanakh «Grani», 3, 22-26 [in Ukrainian]. 9. Sviatnenko, I.O. (2017). Nasylstvo v hendernii kulturi: problema pobudovy typolohii (chastyna 2) [Violence in gender culture: the problem of constructing a typology (part 2)]. Naukovo-teoretychnyi almanakh «Grani», 4, 35-40 [in Ukrainian]. 10. Sviatnenko, I.O. (2017). Deviatsii v ukrainskii hendernii kulturi: sotsiosystemolohichnyi aspekt [Deviations in Ukrainian Gender Culture: Socio-Systematic Aspect]. Naukovo-teoretychnyi almanakh "Grani», 6, 17-22 [in Ukrainian]. 11. Zos'ka, Ja.V., Medvedeva, Ju.Ju., Romanenko, Ju.V., Svjatnenko, I.A., Tulenkov, N.V., \& Homeriki, E.A. (2016). Jetnicheskaja identichnost': sociosistemologicheskoe izmerenie geopolitiki [Ethnic Identity: Socio-systemological Dimension of Geopolitics]. Ju.V. Romanenko (Ed.). Kiev: Merk'juri-Podol'e [in Russian]. 
12. Dobbins, M.-P., \& Mulligan, J. (1980). Black Matriarchy: Transforming a Myth of Racism into a Class Model. Journal of Comparative Family Studies, 11 (2), 195-217.

13. Shohin, V.K. (2006). Filosofija cennostej i rannjaja aksiologicheskaja mysl' [The philosophy of values and early axiological thought]. Moscow: Izd-vo RUDN [in Russian].

\section{Іван Олександрович Святненко}

Докторант

Класичний приватний університет

69000, м. Запоріжжя, вул. Жуковського, 70Б

\section{Ivan Svyatnenko}

Doctoral student

Classical private university

70b, Zhukovsky str., Zaporizhzhya, 69000, Ukraine

Email: magellan4x4@ukr.net

ORCID: 0008-0006-5896-6273

Цитування: Святненко I. О. Гендерні стандарти та очікування щодо сексуальних відхилень у гендерній культурі України / І. О. Святненко // Науково-теоретичний альманах «Грані». - 2019. - Т. 22, № 1. - С. 102-109.

Citation: Svyatnenko, I.O. (2019). Henderni standarty ta ochikuvannia shchodo seksualnykh vidkhylen u hendernii kulturi Ukrainy [Gender standards and expectations on sexual deviations in the gender culture of Ukraine]. Scientific and theoretical almanac «Grani», 22(1), 102-109.

Стаття надійшла / Article arrived: 16.12.2018

Схвалено до друку / Accepted: 18.01.2019 